\title{
Introduction
}

In 1893, Panagi Vagliano foresaw the future of Greek shipping. In an interview conducted in his office in London and published in a Greek newspaper, a reporter described a casual and confident Vagliano, his "right leg folded on his left one, as he usually did, looking towards the window with a childish laugh." Vagliano told the reporter, "I imagine the Greek steam shipping colossal and the Greek shipowner so big that you cannot imagine." When Vagliano gave this interview, Greek nationals owned only 1 percent of the world's shipping fleet. Eighty years later he was proved right: by the 1970s, Greeks owned the largest fleet in the world and Greek shipping tycoons were among the wealthiest people on earth. In the mid-1970s, the Onassis group of shipping companies was one of the world's ten largest independent tanker-owning companies, along with a number of other Greek shipowners. ${ }^{2}$ According to the Review of Maritime Transport 2018, "Greece with $17.3 \%$ of world tonnage expanded its lead." 3

The Greek shipping industry originated in networked family enterprises dating back to eighteenth- and nineteenth-century island shipping companies. These small, family-owned companies evolved into international trading companies like Panagi Vagliano's, and then reinvented themselves during the twentieth century into ship management and global maritime business groups like Aristotle Onassis's. Creating Global Shipping follows these two leading Greek firms, Vagliano's in the nineteenth century and Onassis's in the twentieth, to explain how Greek firms evolved, survived, and thrived between the 1820 s and 1970s, eventually gaining international competitive advantage within the shipping sector.

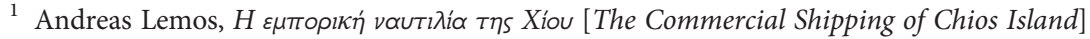
(Chios: privately published, 1963), 407.

2 The Role of Independent Tanker Owners, H. P. Drewry Shipping Consultants Ltd, London, 1976.

${ }^{3}$ Review of Maritime Transport (New York: UNCTAD, 2018), 22,29. Greece was followed in 2018 by Japan, China, Germany, and Singapore. Together, the top five shipowning countries control more than half of the world tonnage (dwt). Five of the top ten shipowning countries are from Asia, four are European, and one (the United States) is from the Americas. 
The Vagliano brothers, though generally unknown to the wider public, were the first Greek tycoons of the nineteenth century. They were major shipowners, bankers, and traders with Imperial Russia, and, in the City of London, were comparable to the Schröders and the Rothschilds. Aristotle Onassis, a more recognizable name, was the quintessence of a twentieth-century shipping tycoon. He became a household name globally, mostly through his marriage to Jacqueline Kennedy, widow of President John F. Kennedy. Both the Vaglianos and Aristotle Onassis left assets of about $\$ 2.8$ billion each (in 2018 values) when they died.

My study shows how these two companies evolved as agents of the integration and globalization of the world economy. Shipping enterprises have always been important agents of globalization, and the Vagliano and Onassis enterprises reveal this crucial context. They opened new markets and linked them with the international economy, working in multiple states and surviving confrontations with many different political regimes. They managed to become competitive in the international economy by creating new business methods and organizational models, and through the formation of networks of shipping, trade, and finance. Meanwhile, Vagliano and Onassis were busy inventing - and continually reinventing - their own maritime business culture and institutions, all designed to fit global norms. Their story identifies the mechanisms, interfirm family networks, and institutional flexibility that underpinned the survival of Greek shipping. Both the Vagliano and Onassis business activities demonstrate how Greeks, by serving the sea routes of the major economic powers of the time (the British and the Russians from the 1820 s and then the United States from the 1940s onwards), created the global shipping industry.

My book builds on the recent work of Michael Miller, who has sought to locate shipping and ports in the prevailing historical narratives of global business. ${ }^{4}$ He highlights how Europeans ran the maritime world by weaving local maritime regions into an interconnected whole - a global system. Miller has provided the first integrated approach to the study of the mechanisms of shipping businesses and the contribution of maritime industry to globalization. However, Miller's work has focused on liner/container shipping, big ports, and northern European enterprises. The plethora of small-, medium-, and largescale tramp and bulk shipping, traditionally connected with localized maritime communities and ports from the Baltic to the eastern Mediterranean and the Black Sea, has escaped the attention of historians writing about shipping. These smaller shipping communities, acting outside of the big maritime centers, are an integral and understudied part of the maritime industry.

${ }^{4}$ Michael Miller, Europe and the Maritime World: A Twentieth-Century History (Cambridge: Cambridge University Press, 2012). 
Tramp and bulk shipping made possible a global supply line for basic resources like food, energy, and raw materials for industry. This book reveals how Greeks in the south of Europe contributed to the evolution of regional European maritime businesses to serve the global economy. Historically, tramp shipping, the part of the industry which carries bulk cargoes on demand, consisted of multiple small companies which were either too difficult to research or else considered marginal. ${ }^{5}$ Tramp ships also did the dirty work of carrying bulk cargoes like coal, fertilizers, minerals, grain, cotton, or oil. ${ }^{6}$ They carry more than two-thirds of the world's sea trade and they are highly significant in the running of the world economy. Yet despite their importance, there has been remarkably little research on tramp- or bulk-shipping companies in the last twenty-five years, with a few notable exceptions. ${ }^{7}$ Moreover, there have been no scholarly studies of individual Greek shipping companies, partly because these were family companies with scattered, fragmented archival resources. ${ }^{8}$ Moreover, many of the important shipowners are not easily accessible, or have not been open concerning their private lives or their business practices. It is no wonder that there are extremely few scholarly accounts of Onassis's business. ${ }^{9}$

Such lacunae in historical scholarship make even more glaring the fact that the history of modern bulk and tramp shipping (and, as we shall see, the global economy itself) simply cannot be written without the Greek example. Local ports and islands - small-scale loci for regional trade - triggered regional development by acting as cradles for the development of larger maritime firms,

${ }^{5}$ Gelina Harlaftis and Ioannis Theotokas, "European Family Firms in International Business: British and Greek Tramp-Shipping Firms," Business History 46, no. 2 (April 2004): 219-255.

${ }^{6}$ Gelina Harlaftis and John Theotokas, "Maritime Business during the Twentieth Century: Continuity and Change," in C. T. Grammenos, ed., Handbook of Maritime Economics and Business (London: Lloyd's of London Press, 2002), 9-34.

7 With the important exception of Gordon Boyce in his Information, Mediation and Institutional Development: The Rise of Large-scale Enterprise in British Shipping, 1870-1919 (Manchester: Manchester University Press, 1995). See also Forbes Munro and Tony Slaven, "Networks and Markets in Clyde Shipping: The Donaldsons and the Hogarths, 1870-1939," Business History 43, no. 2 (April 2001): 9-50. For the Norwegians, Atle Thowsen and Stig Tenold, Odfjell: The History of a Shipping Company (Bergen: Odfjell ASA, 2006).

8 The only study that exists contains 150 short maritime business family histories. See Ioannis Theotokas and Gelina Harlaftis, Leadership in World Shipping: Greek Family Firms in International Business (Houndmills, Basingstoke: Palgrave Macmillan, 2009).

9 See Gelina Harlaftis, "The Onassis Global Shipping Business: 1920s-1950s," Business History Review 88, no. 2 (summer 2014): 241-271; Geoffrey Jones and Paul Gomopoulos, "Aristotle Onassis and the Greek Shipping Industry," 9-805-141, rev. October 18, 2008, Harvard Business School; Theotokas and Harlaftis, Leadership in World Shipping; Gelina Harlaftis, Greek Shipowners and Greece, 1945-1975: From Separate Development to Mutual Interdependence (London: Athlone Press, 1993). 
and through shipping articulated connections to larger financial and commercial centers. The vehicle of shipping is the European shipping enterprise, which played a key role in the promotion of regional and intercontinental trade and economic development. Ultimately, Greek ships were the vehicles of the global economy.

Creating Global Shipping begins by tracing the evolution of European shipping firms. Given that maritime Europe ran world shipping up to the end of the twentieth century, it is remarkable that the evolution of European shipping companies is still understudied. However, its "invisibility" in academic discourse is not just the result of maritime historians and economists failing to highlight their field of study in the context of more traditional analyses of economic and development. It is also a reflection of the nature of shipping itself. ${ }^{10}$ Shipping is not easy to research. Its production (sea transport) takes place beyond national boundaries, and its income is earned abroad and thus usually removed from the economic structures of a specific country. Furthermore, the earnings of shipping companies are difficult to estimate and analyze since their activities are global. In some cases, historians have studied major shipping companies in the context of the growth of trading companies and business groups, but these histories tend to marginalize the shipping component. ${ }^{11}$ Furthermore, the analysis of European maritime businesses has until recently been fragmented either by nation or by sector. This study places shipping at the center of the story of global economic development, and demonstrates how Greek shipping exemplified the crucial shift from regional economies to a global whole.

I identify four stages of development in the history of European shipping, the transitions between them stemming from a series of exogenous and endogenous factors. Greek shipping follows the same path. The exogenous factors come from the evolution of world shipping: in other words, the various economic, technological, and political developments that led to the specialization of world markets in liner and tramp shipping and the appropriate development of shipping firms to serve those markets.

The endogenous factors, meanwhile, can be traced within the "black box" of shipping companies themselves; "mysterious" mechanisms which this book partially pries open. My purpose, by focusing on the two case studies of the Vaglianos and Onassis, is to identify the factors that led to the creation of global shipping - in other words, the path from local to global. These factors, not surprisingly, highlight the success of the Vaglianos and Onassis as entrepreneurs. First, both recognized important opportunities and made decisive

${ }^{10}$ Gelina Harlaftis, Stig Tenold, and Jésus M. Valdaliso, eds., "World's Key Industry": History and Economics of International Shipping (London: Palgrave MacMillan, 2012).

${ }^{11}$ Geoffrey Jones, Merchants to Multinationals: British Trading Companies in the Nineteenth and Twentieth Centuries (Oxford: Oxford University Press, 2000), 1. 
judgments, usually ones connected with risk and uncertainty. Second, each came from an institutional environment that formed and determined individual entrepreneurial ability; environments on which each tended to rely. Third, the Vaglianos and Onassis each adapted and used effective social networking in order to collect and disseminate information and use it accordingly. These personal networks were systems of information that decreased uncertainty and transaction costs. Fourth, they innovated - not only in technology but also in management. Fifth, they demonstrated the ability to raise finance. And last but not least, each displayed a distinctive business philosophy and culture, characteristic of the entrepreneur, that determined the management and organization of their material and human resources. In order to trace entrepreneurship historically one has to trace a businessman's entrepreneurial activities within the market system and within his own business; to investigate how he identified opportunities and how he assembled resources to exploit those opportunities. $^{12}$

The Vagliano brothers represented an archetypal multinational family firm of the Greek diaspora, developing a Russian and then a British international trading company, which led the way in international networking and pioneered the business practices that continue to be used in Greek shipping companies today. They were a prime example of leadership, innovation, expansion, and readjustment of business networks. From the Ionian island of Cephalonia, then a semi-British colony, the Vaglianos started their careers as merchant captains in the 1820s, following the long maritime tradition of their island, and were able to exploit the opportunities available during the era of Pax Brittanica and the First Industrial Revolution. Entering into business during a transitional era for eastern Europe, they seized opportunities offered by the Russian colonization of the northern and eastern coasts of the Black Sea, which transformed the area into the world's preeminent grain-exporting market during the course of the nineteenth century. The Vaglianos were

${ }^{12}$ For all aspects of approaching a business see Geoffrey Jones and Jonathan Zeitlin, eds., The Oxford Handbook of Business History (Oxford: Oxford University Press, 2008). For entrepreneurship in Greek shipping companies see Ioannis Theotokas, "On the Top of World Shipping: Greek Shipping Companies' Organization and Management," Research in Transportation Economics 21 (2007): 63-93; Robert F. Hébert and Albert N. Link, "In Search of the Meaning of Entrepreneurship," Small Business Economics 1 (1989): 39-49; Gordon Boyce and Simon Ville, The Development of Modern Business (Basingstoke: Palgrave, 2002), 264-268. Also for networks in the shipping industry see Gordon Boyce, Co-operative Structures in Global Business (London: Routledge, 2001). See also Mark Casson, The Entrepreneur. An Economic Theory, 2nd edn (Cheltenham: Edward Elgar, 2005, repr. 2008), 43; Mark Casson, Bernard Yeung, Anuradha Basu, and Nigel Wadeson, "Introduction," in Mark Casson et al., The Oxford Handbook of Entrepreneurship (Oxford: Oxford University Press, 2006), 1-30; Mark Casson, "Entrepreneurship and the Theory of the Firm," Journal of Economic Behavior \& Organization 58 (2005): 327-348. 
among the pioneers that integrated the Black Sea grain market with the West. As they transformed themselves into a top Russian exporting house, they opened up routes to the frontier markets of Russia. They were owners of dozens of sailing ships involved in bulk shipping, invested in the new technology of steam, and invented business methods that affected not only the path of their own firm but also the entrepreneurial Greek network that they led.

The Vagliano brothers' business administration helped them to develop the necessary mechanisms to construct strong links with the powerful British economy and its infrastructure. The adoption of new technology, in the form of steamships and their operations, had long-lasting effects within the circle of their cluster group: it diffused expertise and connected it with the pulse of British economic development and industrialization. Ultimately, the choices made by this one company charted the course of their home country's national fleet in the transition from sail to steam. The Vagliano House provides a paradigm of the transformation of an island shipping company to an international trading house. The firm later reinvented itself into a major shipowning and ship-management firm based in London, providing a model for imitation by others, thus opening the path to the global routes of twentiethcentury Greek-owned shipping.

Almost all analyses of Greek shipping tycoons and of the post-World War II Greek shipping "miracle" disregard the long continuity of a business in which Greeks had already developed and shown remarkable entrepreneurship and expertise. The Onassis story, presented as a paradigm of the Western capitalist rags-to-riches tale, is part of this long tradition. Born in 1904, in the cosmopolitan Ottoman port city of Smyrna, Onassis, a son of a tobacco merchant, was raised in a bourgeois milieu. He emigrated to Argentina and seized the opportunities offered by the tobacco trade there. This tranche of capital facilitated his timely entrance into shipping in the early 1930s. Onassis ensconced himself in the community of Greek ship-management offices based in London and was able to take advantage of their human resources expertise by employing experienced managers and seamen from the Ionian island of Ithaca. As an outsider in the shipping industry, he was able to recognize the strengths of traditional Greek and Norwegian shipping practices and thereby reinvent the business of oil transportation through the infrastructures of London and New York markets, as world financial and maritime power shifted from Britain to the United States. In this way, he provided a new model of exceptional organization and administration for his shipping business that remained untouched by the conflicts he later encountered. Consequently, his business organization became a model for imitation.

Onassis's entry into the shipping industry in the 1930s coincided with a transitional era for shipping within the world economy. The decline of the gigantic British shipping groups (battered as they were by the economic crisis of the 1930s), the decolonization that brought an end to the British Empire, 
World War II, and the rise of oil as the world's primary energy source, all combined to transform the world's sea-transport systems, and at the same time created opportunities for the Greek shipping industry. In the immediate postwar era, Onassis was among the prime movers in tankers, ready to exploit opportunities offered by the outcome of the massive American shipbuilding programs during World War II and the spectacular rise of the global oil trade. Greek shipowners were able to exploit these opportunities far better than was the case for their main competitors, the Norwegians, who were handicapped by their nation's decision to prohibit the purchase of foreign vessels. The Greeks engaged with the United States, the world's new economic power in the wake of war, as their main trading partners, as they had done with Great Britain and Russia in an earlier period. This was the advantage of cross-border traders and of tramp owners: by serving international trade rather than the needs of a particular nation, they were able to adjust rapidly to changes in the world environment.

This book aspires to tell a new story: the emergence of global shipping enterprise through the paradigm of the growth and transformation of two Greek enterprises. It is partly due to the pioneering activities and remarkable metamorphosis of these two businesses that at the turn of the twenty-first century Greek shipowners still had the largest fleet in the world. These Greek companies were responsible for carrying on the European maritime tradition and reinventing it with their British and American partners to create the global shipping sector.

\section{The Archival Odyssey}

The first great challenge of the research into these two businesses was that there were no available and organized archives; I had to construct them. As these were network firms engaged in activities from Russia to the Americas, and therefore characterized by great mobility, I had to travel to discover their traces. In the course of a few decades of my research into Greek shipping, the Vaglianos had repeatedly caught my interest. Whether I was in Athens or London, or on whatever Greek island I wanted to research in local state or private archives for the period from the 1830s to the 1900s, there would be a Vagliano: a charter party, a letter, a crew list, a logbook, or an insurance contract. Indeed, it seemed that there was not a single part of the development of the shipping industry in the nineteenth century that was not influenced by these brothers. However, despite the Vaglianos' importance, nothing had been written apart from short biographies on their business. Greeks knew that they were important, but nobody knew their true significance. It was in the summer of 2006 at the General State Archives of the Prefecture of Cephalonia that I discovered a Vagliano Archive that included mostly business archival material from the last years of the Vaglianos' London shipping office. It contained 
books of correspondence of Panagi Vagliano and his nephews, leather-bound large-format books containing insurance contracts drafted by the Vagliano Bros for their own ships and for those of clients, double-entry ledgers of transactions conducted at the London office, ledgers with the transactions of the company's clients and collaborators in shipping, trade, finance, etc. There were also some twenty files relating to cases of claims from the insurance companies of several steamships, insurance contracts, excerpts from logbooks, payments of invoices for compensations, bills of lading, freight agreements, court rulings on averages, correspondence between Greek captains and the Vagliano office, receipts of suppliers, and more. The archive also contained documents on the function of the Vagliano Bequest in Cephalonia during the first half of the twentieth century. Consequently, despite its fragmentation, the Vagliano Archive provided the foundation for my research needs.

Next, to England. There was some material to be found about the Vaglianos in the National Archives at Kew Gardens, including British censuses, consular reports, naturalization of members of the Vagliano family, documents on steamship companies, and other similar historical documents. However, the most valuable find was at the Archive of the Bank of England. In huge volumes, there were tens of thousands of transactions of the accounts of the Vagliano Brothers from 1858 to 1887 - a completely unexpected harvest. ${ }^{13}$

I found more material in the Archives of the National Bank of Greece, where there are files with the correspondence from Andrea Vagliano in Constantinople, as he was an agent of the National Bank of Greece. The private archives of Captain Anastasis Syrmas (from the island of Andros) and Captain Alexandros Arvanitis (from Galaxidi) found in the Hellenic Literary and Historical Archive also confirmed the connections of various captains with the Vagliano family. Most precious proved to be the Coutsis Archive on the island of Spetses, which held a few hundred letters of correspondence from the Coutsis shipping firm with all three Vagliano brothers. However, the evidence above provided mainly evidence on Panagi and Andrea Vagliano. Mari Vagliano, the eldest brother and the one who initially set up the business, seemed to be lost in Russia.

It was in September 2007 that I traveled for the first time to Russia. There, in Taganrog, the adopted hometown of Mari Vagliano, I saw his house and traced his story through local and popular historical books. Mari Vagliano was referred to as the multimillionaire, the "Tsar," the great capitalist of the

${ }^{13}$ Based on the wealth of information found in the Bank of England's Archives for Greek merchant bankers who were established in the City of London, I decided to continue the research with Dr Katerina Galani in a postdoctoral research project in 2013-2015, "From Constantinople to the City of London: Greek Merchant Bankers, 1820-1880.” The project was co-funded by the EU, and the Greek Ministry of Research and Development, in which I was the scientific advisor. 
area. In the State Archives of the Rostov-on-Don region, I discovered details about a major trial that took place sometime in the 1880s or 1890 s but nothing more, and the libraries did not have any newspaper archives for me to review. Although Russians had not forgotten Mari Vagliano, a larger-than-life figure to whom was attributed all the negative connotations of capitalism during the Soviet and post-Soviet era, there was little research about him, and hard data was frustratingly thin on the ground. What there was, was parochial and journalistic.

After correspondence with the Kharkov and Kiev archives in Ukraine, I decided to head to Kiev in June 2009. There I discovered more traces of Mari Vagliano. From 1881 to 1886, he featured in the headlines of Russian newspapers in Odessa, Moscow, St. Petersburg, Kiev, and Kharkov, to name but a few cities. There was a large file related to a court case in the Kiev Archives on "Taganrog Customs" with documents from interrogations and examinations, along with commercial documents of the daily work of the merchants and the Customs employees under accusation. Further research in Taganrog, Rostov-on-Don, Kiev, Odessa, Moscow, and St. Petersburg provided rich material and valuable statistics on the overall importance and participation of all exporters from southern Russia in value and quantity from the 1810 s to 1910 s. This material placed Mari Vagliano in perspective and documented his importance not only in the Black Sea region but also in the whole of Russia. ${ }^{14}$

14 This material was further enhanced from the major research interdisciplinary and interuniversity project "The Black Sea and its Port-Cities, 1774-1914: Development, Convergence and Linkages with the Global Economy" that took place from 2012 to 2015; the project was included in the Action "Thales," financed by the Greek National Strategic Reference Framework, the EU and the Greek Ministry of Education. The project was led by the Department of History of the Ionian University, with Gelina Harlaftis as project leader. It was a collaboration, on a national level, with the University of Crete, the National Hellenic Research Foundation, the Institute for Mediterranean Studies-FORTH, the University of Thessaly, and the University of the Aegean. On an international level, it collaborated with twenty-three academic institutions - universities, research institutes, and archives - from the Black Sea countries, that is Turkey, Bulgaria, Romania, Ukraine, Russia, and Georgia, as well as from Moldavia, Norway, Italy, Israel and the United States. The collaborating group consisted of the following academic institutions: Boğaziçi University, Bilkent University, Düzce University, and 19 May University from Turkey, Bulgarian Academy of Sciences and Varna University from Bulgaria, Dunarea De Jos University of Galati from Romania, Moldavian Academy of Sciences from Moldavia, State Archives of Odessa, State Archives of Nikolaev, National Academy of Sciences of Ukraine, University of Berdiansk, University of Mariupol, and University of Kharkov from Ukraine, Russian Academy of Sciences (Moscow), Southern Russia Academy of Sciences (Rostov-on-Don), State Russian University of Human Studies, European University of St. Petersburg, and State University of St. Petersburg from Russia, Elia State University (Tiblisi) from Georgia, Jerusalem University from Israel, Southern State 
My engagement with Aristotle Onassis and his shipping company was more experiential than that with the Vaglianos. In October 1968, at the age of ten, I was in the Naval Hospital of Athens recovering from tonsil surgery (my father was a naval officer). My mother brought magazines to pass the time while sitting with me. I "met" Onassis, who at the time was getting married to Jackie $\mathrm{O}$ on the island of Skorpios, through the lengthy articles on his life contained in the magazines. Ever since then I, along with millions of other Greeks, have followed his life.

However, writing about Onassis for this project has proved both fascinating and frustrating. As he attracted the world's attention, he was featured in the headlines of newspapers and magazines around the world for years, which means there are stories about him everywhere. There are thousands of articles (the New York Times alone has more than 4,000 columns on Onassis), with still more being produced more than forty years after his death. Reporters, journalists, gossip columnists, novelists, storytellers, popular writers, and moviemakers have turned Onassis into an important figure in the world's popular culture. A mythology has been built around Onassis and reproduced over the years. But for the scholar, this is problematic. Almost none of the books on Onassis are based on scholarly research; their authors include only the most general and vague references. How should the academic approach this mythology?

It was not easy, as it turned out. No company archives were available on the Onassis business, as far as I knew when I started this book. I needed to find archives elsewhere, such as those of the Federal Bureau of Investigation and the Congressional Committees on Onassis companies, along with the Lloyd's Register and those available from press organizations. ${ }^{15}$ It was only in 2015 that I decided to apply to the Onassis foundation in the event they had any archives. I held out little hope of a response, as Greek shipping firms are notorious for being suspicious of researchers. There is no culture of maritime business archives and the knowledge related to the largest shipping fleet in the world is in danger of falling into oblivion, as it does not take care of its recent history. There is not a single shipping archive from the mid-twentieth century to the present day that is appropriately organized and open for research, in Greece or abroad. Hoping against hope, I wrote to Dr. Anthony S. Papadimitriou, President of the Alexander S. Onassis Foundation. To my amazement, he responded positively and asked me to meet him at the Foundation. What followed was beyond my expectations.

Connecticut University from the United States, and Maritime Museum of Bergen from Norway. The website is www.blacksea.gr.

15 The FBI archives consist of two main files of about 1,000 pages each: Archives of the Federal Bureau of Investigation (FBI), "Aristotle Onassis," part 1, Bufile 100-125834 and parts 2, 3, and 4, Bufile 46-17783. 
I found that he, his predecessors, and the Board of Directors of the Onassis Foundation, with respect to their heritage, have saved an impressively rich body of archival evidence from the Onassis business companies around the world. In fact they kept the records of the Onassis business from 1939 to 1975 (and after) and have gathered them together from the offices in Montevideo, New York, and Monte Carlo to Athens. The archival material, in hundreds of boxes, contained corporate books with statutes and minutes of Board Meetings of more than 200 Panamanian and Liberian companies, ledgers of monthly accounts of companies, crew and wage lists, technical specifications of ships, insurance contracts, charter parties, loan agreements, sales and purchases of ships, court cases, and the general balances of all companies. There was also the internal and external correspondence of CEOs and other high-level employees, ship logbooks and medical logbooks, indemnities of seamen, photographic material (for example photographs and booklets of ship launchings), and extracts of publications on the Onassis family. I could have drowned in all this material, to which I was given unrestricted access; it would need a few years to systematically study and process. Nonetheless, in a few months of research I was able to gather a valuable sample of the material that proved clearly what Aristotle Onassis did, how he structured his business empire, and the importance of his role in the creation of the global shipping business.

Fellow historians can understand the excitement of opening dusty boxes of unseen documents of the Onassis business for the first time after a few decades of concealment. The financial results of his ledgers were exciting enough, but it was also amusing and moving to find other, more personal, material. For example, in the files of the company that dealt with his personal expenses were the bills for Jacky O's Valentino dresses in 1970, or the monthly allowance he sent to his Norwegian first partner, Ingeborg Dedichen, in 1966, more than twenty years after their separation. In full detail, there are records of his family and house accounts around the world, while the logbook of his flagship Christina is also there from the beginning to the end, with detailed lists of its famous passengers. In another box, there were several books that belonged to Christina Onassis. As I was browsing a copy of Carl Bernstein and Bob Woodward's All the Presidents' Men, published in New York in 1974, a small note escaped the pages and fell. It was from a concierge in a hotel in New York: "RM 3903 ... Miss Onassis. Your father called from Paris. 10.10 pm." Could it be that her father called her from the hospital in Paris? But as fascinating as they are, none of these personal items will be included in this book. What needs to be produced is not another popular interpretation and exposé of his well-known personal life, but a serious effort to understand the significance of his shipping business, and through it his contribution to global economic growth.

Many times I have thought that I should have written a novel, not an academic history, about the Vagliano family and Aristotle Onassis. A novel based on real facts, such as the excellent The Hare with Amber Eyes by 
Edmund de Waal who, through an art collection, unfolds the history of the Ephrussi, a Jewish diaspora trading family that started its business in southern Russia (and, incidentally, a business collaborator of Mari Vagliano). Alternatively, perhaps I could have written something like John Galsworthy's Forsyte Saga. The Vaglianos resided in Kensington, and had a lifestyle equivalent to the Forsytes, being one of the commercial upper-middle-class families of Victorian London. Writing a multigenerational saga of rich families scattered around the world, with descendants living on the founders' money, would have been tantalizing.

I could also have written a novel about those family businesses in Taganrog, Constantinople, Cephalonia, Marseilles, London, Oslo, Buenos Aires, New York, or Monte Carlo. This is the familiar Onassis legend: lavish homes, enormous fortunes, balls, receptions, private yachts, private islands, love stories, and scandals. I would certainly have loved to visit the houses of my four protagonists. To drink tea from the samovar with Mari Vagliano in Taganrog, or coffee with Andrea in Constantinople, or in London with Panagi, or go and listen with Ari Onassis to the Diva in the Scala di Milano. Spending so many years immersed in the activities of these four men, I feel I have penetrated their daily lives, walked in and out of the myth and the reality, lived in the romance and the ferocity of more than one bygone era.

This book could also have been a good detective story. It would take place in the Imperial Russia of the Tsars, in Victorian England, and in the Cold War era of the United States and Soviet Union. It would follow the Russian Imperial police putting the multimillionaire Mari Vagliano in jail and under scrutiny, and watch his celebrated trial in the Russian courts advertised all around Russia. It would then follow FBI and CIA agents spying on Aristotle Onassis, or British detectives following Panagi Vagliano in the City of London.

But history can transcend the imagination of the novelist - unless we make it so serious and scientific as to dry it out. As R. W. Southern wrote, when historians "began to take a more prosaic view of historical facts and to distinguish more rigorously between fact and fancy ... the end was in sight for history as an art conceived in terms borrowed from the ancient world: Romance became separated from History. Art and science went their different ways to separate heavens, and history flees between the two." ${ }^{\text {"6 }}$

This book is the story of the life voyages of citizens of the world, of "polites" (citizens, in Greek) of "cosmos" (world, in Greek), that is of cosmopolitan people. These were citizens of a pan-cosmian (all-world, in Greek), or global society. As the Vagliano brothers and Aristotle Onassis are connected with the islands that claim Ulysses, Cephalonia and Ithaca, they are connected with the

16 R. J. Bartlett, History and Historians: Selected Papers of R. W. Southern (Oxford: Blackwell Publishing, 2004), 29. 
periplous, the continuous wandering along the sea routes searching for business and profit. They all had boldness: the nerve to reach out to foreign lands and to sail in unchartered waters. Their business life stories, I submit, link us with Hellenic myth, as hands touching across a vast gulf. Myths and heroes can be prototypes to be admired or hated, and can become stereotypes and paradigms to follow or avoid. Mari, Panagi, and Andrea Vagliano managed to do this on a local, regional, national, and international basis. Aristotle Onassis made it global.

This book has taken a very long time to complete, not least because I had such good fun traveling and doing research tracing their activities that I did not want it to end. A book, however, becomes alive when it ends and follows its own path into the world. A hundred and six years after the last Vagliano's death and forty-three years after Aristotle Onassis's, I realized it is time to let it go. May the reader enjoy reading it as much as I enjoyed writing it. 